\title{
Evaluation of Corporate Governance Measures: An Application to the Australian Higher Education Sector
}

\author{
Chitra De Silva and Anona Armstrong \\ Victoria University, Australia
}

\begin{abstract}
Governance has emerged as a major concern in the higher education sector. Although evaluation of performance of governance is widely used in the private and public sectors, little attention has been given to the assessment of good governance practices in university contexts. The purpose of this paper was to describe the changes in government policy associated with the introduction of Governance Protocols that have impacted on the higher education sector and to answer the research question: do Australian Universities apply the best practice corporate governance measures?. Data for the study were compiled from annual reports and the Web pages of 37 publically funded universities in Australia and Selected Higher Education Statistics Collection. The assessment criteria were derived from the National Governance Protocols. Findings revealed that Australian universities as independent corporations apply the universal best practice corporate governance indicators as governance measures.
\end{abstract}

\section{Keywords}

Corporate governance; Universities Protocols; higher education

\section{Introduction}

Corporate governance issues in both the private and public sectors have become a popular discussion topic in the last two decades (De Silva 2011). In a move to improve on their governance arrangements, legislative changes and provisions have been imposed by governments on public and private organizations around the world (Edwards 2000). Universities have been one of the 'interests caught up in the international surge in governance of organizations' (Dixon \& Coy 2007, p. 267), not least in the Australian context. The Australian higher education sector has grown dramatically in the past two decades. Student numbers have doubled from 534,510 student enrolments in 1991 (DEEWR 2009) to over a million in 2009, 813,896 are domestic and 320,970 are international students (DEEWR 2011). According to the Review of Australian Higher Education Report, 2009 (DEEWR 2011) full time equivalent staff load has grown to around 107,221 and total revenue exceeded AUD 19.9 billion in the year 2009. The sector now comprises: 40 universities of which 38 are public institutions and 2 are private; one Australian branch of an overseas university; 4 other self-accrediting higher education institutions; and more than 150 non-self-

Copyright (C) 200x Victoria University. This document has been published as part of the Journal of Business Systems, Governance and Ethics in both online and print formats. Educational and non-profit institutions are granted a nonexclusive licence to utilise this document in whole or in part for personal or classroom use without fee, provided that correct attribution and citation are made and this copyright statement is reproduced. Any other usage is accrediting higher education providers listed on State and Territory registers and accredited by State and Territory authorities. Several universities and private providers operate in more than one State and (DEEWR 2011) thirty five of the 40 higher education providers now have annual incomes of more than $\$ 100$ million. 
Table 1. Major government policy initiatives in the Australian Higher Education sector

\title{
Higher Education Policy Initiatives 1995-2000
}

\author{
Hoare Committee Review of Higher Education Management (Hoare 1995); \\ Victorian Ministerial Committee of Advice on University Governance (Storey 1997); \\ West Review (West 1998); \\ Victorian Review of University Governance, (Hamilton 2002); \\ Auditor General, Victoria, Report on RMIT University's finances (Cameron 2003); \\ Nelson Review Backing Australia's Future (2003); \\ (Bradley review )Review of Australian Higher Education (2008). \\ Transforming Australia's Higher Education System (DEEWR 2009)
}

\section{Source: De Silva (2011)}

Numerous higher education inquiries (Table 1) have resulted in policy changes that have affected the funding and operations of universities. Among the most significant was the Our Universities: Backing Australia's Future (Nelson 2003) package of reforms delivered as part of the 2003-04 Budget. The reforms gave universities access to increased funding and, of relevance to this paper, included significant changes to university governance arrangements. The aim of this paper is to discuss the governance reforms that took place in the higher education sector in Australia and analyze the governance performance of Australian universities. This study is of a significant practical importance, because it applies the appropriate corporate governance measures used in the corporate governance literature to evaluate the performance of governance in the university sector

\section{Corporate governance and Universities}

Corporate governance is concerned with the structures and processes for decision-making, accountability, control and behaviour at the top of organisations (Armstrong \& Francis 2004). Governance can be defined as "the system or structure of rules and relationships, supervision and control of those who exercise the authority, accountability, stewardship, leadership, direction and control that aims to ensure accountability and efficient use of resources in balancing the achievement of goals of corporations, society and individuals" (Armstrong and Unger, 2009, p.47).

\section{Governance Reforms in Australian Universities}

According to the 1988 White Paper (Dawkins, JS 1988) the forms of governance in Australian universities were obsolete and had to make way for more efficient and effective corporate models. Further the White Paper (Dawkins, JS 1988) recommended a change in university council structure. Vice-Chancellors were to assume the additional title of Chief Executive Officer (CEO), and universities were to become more 'business-like' and entrepreneurial with smaller council size (10 - 15 members) (Dawkins, JS 1988; Harman, G 2003; Harman, K \& Treadgold 2007). The most significant review of university governance and management, The Higher Education Management Review by David Hoare was conducted in 1995. The Hoare Review (1995) identified shortcomings in university governance arrangements and recommended clarification of the role of the governing bodies, and changes to the size, composition and methods of appointments of members to the governing bodies (De Silva 2011).

Best practice corporate governance has been defined by a number of international agencies. Among the most significant in the Australian context were the OECD (2004) and ASX Corporate Governance Council (2003, 2007) guidelines and principles for corporate governance best practice. Governance standards introduced into the higher education (HE) sector followed these developments in governance in the corporate and business environment, especially adapting the generic principles enunciated by the Australian Securities Exchange, the 
Australian Institute of Company Directors and Australian Standards International (Armstrong and Unger, 2009).

In line with the above guidelines, the 2003 Backing Australia's Future reforms introduced governance best practice guidelines for the Australian university sector in the National Governance Protocols for Public Higher Education Institutions. The Protocols referred to: the responsibilities of the 'governing body' (Protocol 2); procedures for appointment and selection, and the duties of members (Protocols 3, 5 and 6), induction and training (Protocol 4); size (less than 22 members of the body, Protocol 5); and risk management in regard to controlled entities and reporting (Protocols 8, 9 and 10).

Many of these requirements reflect governance 'best practice' as it is described in the above codes and standards of best-practice governance (Armstrong 2004).

The National Governance Protocols for Higher Education (Nelson 2003) imposed obligations on universities for: definition of institutional objectives in the enabling legislation; definition of governing body purposes and duties; systematic professional development programs and performance evaluations of governing bodies; systematic procedures for composition of the governing body, including limits on size of the governing body and specifications of expertise; a majority of independent members in the governing body; codification and reporting of business practices and risk analysis.

These initiatives were designed to ensure consistent criteria and quality of standards across Australia in such matters as the recognition of new universities, the operation of overseas institutions in Australia, and the accreditation of higher education courses to be offered by non-self-accrediting providers (Nelson 2003).

The impact of the reforms on universities was substantial (Swansson, Mow and Bartos 2005). They aimed to make the institutions more competitive in maintaining international standards, offering universities the ability to exercise academic freedom and managerial autonomy while requiring the Council, as the governing body, to take primary responsibility for the governance and performance of universities (Nelson 2003). Complementing theses were the proposals which emerged from the Review of Australian Higher Education Report (Bradley et al 2009) requiring institutions to consider restructuring, establishing their mission, and adopting more vigorous strategies. It was hoped that greater transparency and accountability would increase funding which would be primarily driven by, first, student choice, and second, the success of institutions in attracting competitive funding allocations and generating revenue from other sources.

In the past governments exercised control over universities through the conditions attached to their funding. The largest share of funding (55\%) for a publically funded university in Australia comes from the Commonwealth Government (Universities Australia, 2010, Bradley et al 2009). The reforms introduced in Backing Australia's future (Nelson 2003) empowered Universities to assume more autonomy but at the same time required more accountability. The responsibility for the governance and management of a university is typically vested through State legislation in a governing body such as a Council or Senate. Every university's enabling legislation provided for the governing body to have overall control and management of their university (Nelson 2003). The Chancellor and the Vice-Chancellor are equivalent to the Chair of the board and the Chief Executive Officer in the private sector.

Fielden (2008) presented four different models of university governance (Table 2): institutional control, state control, semi-autonomous and independent. The Australian Model was identified as an independent model. It was believed to produce better performance, as the Australian universities have the power to make their own decisions and control their own destiny. 
Table 2: Four Models from Control to Autonomy

\begin{tabular}{l|l|l}
\hline $\begin{array}{l}\text { Institutional } \\
\text { Governance } \\
\text { Model }\end{array}$ & $\begin{array}{l}\text { Status of } \\
\text { public universities }\end{array}$ & Examples in \\
\hline State Control & $\begin{array}{l}\text { Can be an agency of the MOE, or a state-owned } \\
\text { Corporation }\end{array}$ & Malaysia \\
\hline $\begin{array}{l}\text { Semi- } \\
\text { Autonomous }\end{array}$ & $\begin{array}{l}\text { Can be an agency of the MOE, a state-owned corporation or a statutory } \\
\text { body }\end{array}$ & $\begin{array}{l}\text { New } \\
\text { Zealand, } \\
\text { France }\end{array}$ \\
\hline $\begin{array}{l}\text { Semi- } \\
\text { Independent }\end{array}$ & $\begin{array}{l}\text { A statutory body, a charity or a nonprofit corporation subject to MOE } \\
\text { control }\end{array}$ & Singapore \\
\hline Independent & $\begin{array}{l}\text { A statutory body, charity or non- profit corporation } \\
\text { with no government participation and control linked to national strategies } \\
\text { and related only to public funding }\end{array}$ & $\begin{array}{l}\text { Australia, } \\
\text { United } \\
\text { Kingdom }\end{array}$ \\
\hline
\end{tabular}

Source Fielden (2008)

According to Fielden's (2008) model, Australian universities have an incentive to be entrepreneurial and competitive. Any university could choose different ways to respond to national policy goals and they could be more innovative than others particularly by specializing in disciplines or courses, or changing how courses were delivered.

Australian universities have been legally structured as companies or corporations under State or Commonwealth law (Harman, K \& Treadgold 2007). The traditional (collegial) model of governance embodied the philosophy of self-governance with little or no direct government interference, except for the indirect influence of ministerial appointees on council (which is not a practice or a requirement of the current context) (Harman, K \& Treadgold 2007, p. 13).However, universities cannot enjoy unlimited autonomy, because of their inherent purpose of fulfilling the nation's expectations of providing a quality education and participating in innovative research activities. Hence, within the Independent model there is an implicit acknowledgement that the Commonwealth authorities are entitled to hold the institution accountable in many respects and must retain overall strategic control over the sector. The protocols were designed to meet this need.

Even though the university governance protocols in Australia were designed according to the universal best practice corporate governance measures, there is very limited research on governance practices of universities, especially in the Australian context to investigate the application of corporate governance indicators to measure the best practice corporate governance in the university sector. The purpose of this research is to fill this gap in the literature by using the universal best practice corporate governance indicators to evaluate the corporate governance mechanisms in the university sector giving special reference to Australian universities.

\section{The Conceptual Framework}

The conceptual framework (Figure 1) was derived from the governance mechanisms described in the governance literature (Aldridge 2004; Khanchel 2007). Applications of institutional theory to investigate governance have been advocated in the governance literature (Aldridge 2004; Greenwood \& Hinings 1996; Kondra \& Hinings 1998). According to Weir and McKnight (2002), institutional corporate governance consists of external governance mechanisms and internal governance mechanisms. External governance mechanisms are those influences, such as government policy, exerted from outside a university. According to the corporate governance literature (Khanchel 2007, Bhagat and Black 2002), structural composition and the processes of the board characterize a firm's internal governance structure. 


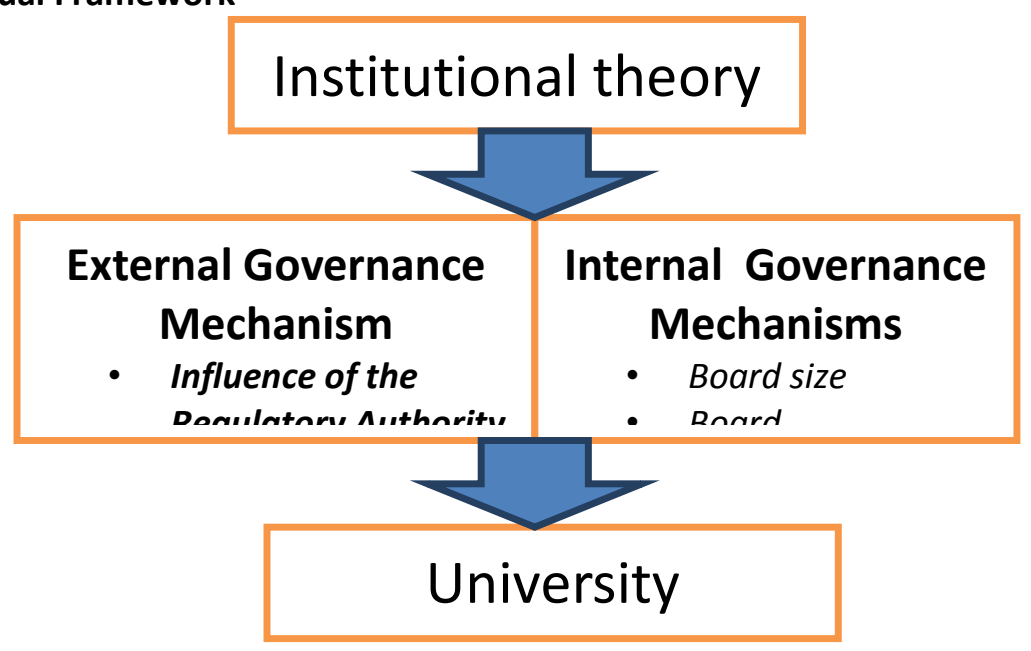

The National Governance Protocols considered the structural composition of universities as an important measure of the governance mechanisms of universities (Protocol 3, 4, 5 and 6). The size (numbers of members in the board) (Yermack 1996) and theextent of independence of the board (Khanchel 2007) were used to analyse the structural composition in the previous studies.In this respect, the greater the structural separation of oversight committees from the management of particular activities such as appointment and remuneration of senior staff, the more robust the governance should be. Particular prominence was given to audit committees that are charged with monitoring strategic objectives, the overall financial performance, reporting requirements and their compliance with 'best practice' corporate governance standards. Board meetings (Shivdasani and Zenner 2004) and transparency in reporting were used as measures for board process as of Khanchel (2007) and used the above measures as indicators in analysing the corporate governance of universities. The board of directors of the universities referred to as the council of the university and the board and the council has used interchangeably in the forth coming paragraphs of this paper.

The corporate governance framework used in this study was similar to the framework used in previous studies conducted by Kyereboah-Coleman and Biekpe (2005), Chen, Elder and Hsieh (2005) and Weir, Laing and McKnight (2002) in the corporate sector. Governance framework of this study consists of internal corporate governance variables and external corporate governance variables. The research questions addressed in this paper was: do Australian Universities apply the best practice corporate governance measures?

\section{Methodology}

Data for the study were collected from the annual reports of thirty seven publically funded universities, and web pages of universities. Bachelors College was excluded from the study due to its special nature.

The criteria for the evaluation in this study were drawn from the Protocols. The data were compiled in a comparative data base and analysed using SPSS. In the current study about governance performance of universities consists of external and internal corporate governance variables.

The external corporate governance mechanism variable, the influence of the regulatory authority, was measured by using the universities' compliance with 2003 National Governance Protocols. The internal corporate governance mechanism variables were board size, board independence, role of standing committees, and board processes indicated by transparency in reporting and board meetings. Internal corporate governance mechanisms such as council size were measured by counting the number of appointed, elected and ex- officio 
members in a council (Chaganti, Mahajan \& Sharma 2007; Eisenberg, Sundgren \& Wells 1998), council independence was calculated as the percentage of external members to the total number of members in the council (Bhagat \& Black 2002) and a council committee index (Appendix 1) was constructed by using the board committee index measures used in the existing literature (Callen, Klein \& Tinkelman 2003; Khanchel 2007; Klein, April 1998). A board committee index was calculated for each university. The variables used to construct this index were audit committees, remuneration committees and nomination committees. Similarly, existence of an audit committee, a chair who was external or not, a majority of external members or not and number of meetings held during the year were considered for audit committees. Existence of a nomination committee, CEO not a member of the committee and existence of a remuneration committee, and CEO not a member of the committee, were considered for remuneration committees (Appendix1).Board meetings held during the year 2007 was used, assuming that a maximum number of meetings for the year should be twelve. The depth and the extent of the information disclosure in the annual reports were used to calculate the transparency index (Appendix 2).

\section{Results}

The following presents the results of the analyses of the measures of internal and external governance mechanisms.

Table. 3 Descriptive Statistics for Governance Mechanism Variables

\begin{tabular}{lccccc}
\hline & $\mathbf{N}$ & Minimum & Maximum & Mean & $\begin{array}{c}\text { Std. } \\
\text { Deviation }\end{array}$ \\
\hline $\begin{array}{l}\text { Comply with protocols } \\
\text { index) }\end{array}$ & & .92 & 1.00 & .9395 & .03480 \\
Board size & 37 & 12.00 & 22.00 & 19.2432 & 2.76290 \\
Board independence & 37 & .50 & .70 & .6000 & .05185 \\
Board committees & 37 & .18 & .76 & .5424 & .14090 \\
Board meetings & 37 & 4.00 & 12.00 & 6.8378 & 1.48162 \\
Transparency in reporting & 37 & .25 & 1.00 & .6038 & .18067 \\
Valid N (listwise) & 37 & & & & \\
\hline Source 2009 reston
\end{tabular}

Source 2009 research

\section{Descriptive Statistics for External Governance Mechanism}

A measure of Compliance with the National Governance Protocols for Higher Education has been used in the current study as the proxy for the influence of the regulatory authority.

\section{Regulatory Index (Influence of the regulatory Authority)}

Universities' compliance with National Governance Protocols was used as the regulatory index of the study. The minimum value for compliance with the protocols was 92 percent and the maximum was 100 percent. The standard deviation was only 3 percent and the mean value of compliance with protocols was a high 94 percent. Compliance with the 2003 National Governance protocols represented the role of the influence of regulatory authority or the regulatory index in the study. Descriptive statistics showed that the mean value of the compliance with the protocols was $94 \%$ at the time of study and this agrees with the findings of the Australian Government Higher Education Report (2005) which confirmed that all the Australian universities have made some effort to comply with 2003 National Governance Protocols by year 2005. Some universities could not address the risk criteria as outlined in the protocols and this brought down the mean value to $94 \%$. 


\section{Descriptive Statistics for Internal Governance Mechanisms}

There were five indices used in the construction of the index of internal governance mechanisms. They were board size, board independence, board committees, board meetings and transparency in reporting. Descriptive statistics for the internal governance mechanism variables presented in Table 3 are followed by the summary in detail.

\section{Board Size}

Descriptive statistics for board size of Australian universities varied from a maximum of 22 council members to a minimum 12 council members. The mean value was 19 members in the council or the governing body of the university. According to the research findings of the study, 8 out of 37 universities had 22 council members and the minimum, 12 council members, were at the Central Queensland University. This confirmed the adaptation of the suggested board size of the Higher Education Protocols (2003). The higher average of 19 members suggested that universities prefer to have larger governing bodies.

\section{Board Independence}

Board independence showed the extent of the appointment of external members in the university councils. Descriptive statistics showed that the minimum value for board independence index was 50 percent at James Cook University and the maximum value, 70 percent, was at Edith Cowen University. The mean value for board independence was 60 percent. This confirmed the protocol (2003) requirement that there should be a majority of external members in the university governing body.

\section{Board Committee Index}

The Board committee index in the current study referred to the process of appointing standing committees to the university council. This variable examined the existence, process and the independence of audit, remuneration and the nomination committees as standing committees in the university governing body (appendix 1). In analysing the process of the audit, remuneration and nomination committees, the number of meetings held and the influence of the Vice Chancellor as the Chief Executive Officer of the University on those committees were also addressed. The maximum value for the board committee index was reported as 76 percent and the minimum value was 18 percent. The mean for the standing committee index of Australian universities was 54 percent. Further investigations of the research revealed that every university has an audit committee and the chair of the committee was an external member. This explained that all 37 universities had independent audit committees. The research results further disclosed only 12 out of 37 universities had remuneration committees and 20 out of 37 universities had nomination committees as of 2007 and other universities were in the process of establishing, remuneration committees and nomination committees.

\section{Board Meetings}

The board meeting index was used as the measure of board process. The number of Council meetings held during the year was used as the measure of board meetings for the present study. The descriptive statistics varied from a maximum of 12 meetings at the University of Melbourne and the minimum 4 meetings held during the year at the Australian Catholic University. The mean value for board meetings showed as 6.8 which could be considered as seven meetings per year. Shivadasani and Zenner (2004) suggested that, boards should increase the frequency of meetings if the situation requires high supervision.

\section{Transparency in Reporting}

Transparency in reporting was measured by using a transparency index. The transparency index was constructed to measure the depth and the extent of information disclosure in the annual reports of the universities in addition to fulfilling the mandatory requirements in reporting for government agencies. The 
annual reports of universities are considered as one of the main instruments that could be reliably used by the external users of information in making informed decisions regarding universities. The minimum value for transparency in reporting was $25 \%$ and the maximum value was $100 \%$ for the University of Melbourne in the index. The mean value of the transparency index was $60 \%$ where the standard deviation was $18 \%$. Statistics showed that on average universities exhibited 60 percent transparency in reporting in their general purpose reports (Annual reports) in addition to fulfilling mandatory disclosure requirements.

\section{DISCUSSION AND CONCLUSION}

Analysis of the Governance structures and process of Australian universities were performed for the year 2007 by using descriptive analysis. All the universities comply with the National Governance Protocol requirement of maximum board (council) size, with a majority of external members. Board committee indices suggest that universities adopted universal best practice, but not every university has nomination and remuneration committees. Though the number of meetings held during the year 2007 was varied among universities the average of seven meetings per year suggests the councils make an effort to regularly screen and monitor the performance of the universities.

The reforms in higher education governance in recent years were driven by internal and external pressures. Some remarkable changes that took place in the governance systems of universities were that every university has established as an autonomous independent entity by its enabling legislation and the withdrawal of the commonwealth and the state government from certain control and management functions, devolution of responsibility to university councils, and adoption of funding models which gives more autonomy and freedom to universities. In other words universities are encouraged to develop new sources of income, which lead to development of new forms of accountability through performance and outcome based funding for universities.

The results of the empirical study revealed that governance structures of the Australian universities are independent and applying universal best practice governance, hence it is appropriate to apply the corporate governance indicators to evaluate the governance mechanisms of universities in the Australian context. Effective governance structures play a very important role in attracting most needed funds, and building stakeholder confidence and reputation and to being competitive in the demand driven Australian university sector.

This study contributed to the existing literature by analyzing the application of universal corporate governance indicators to measure the governance in the university sector. It revealed that Australian universities as independent corporate bodies incorporated under their own individual Acts, apply the universal best practice corporate governance measures to evaluate the performance of the governance mechanism of universities.

\section{References}

Aldridge, I (2004), Why Are Financial Markets Regulated? An Empirical Investigation of Validity of Regulation Theories., Working Paper, Rotman School of Management,University of Toronto, viewed 12/8/08 at $<$ http://www.rotman.utoronto.ca/aldridge/research/Aldridge finreg41304.pdf $>$.

Armstrong, A (2004), 'Commentary on codes of corporate governance', in Armstrong A\& Francis R (eds), Introduction to corporate governance, Standards Australia International, Sydney

Armstrong, A \& Francis, R (2004), 'Introduction', in Armstrong A \& Francis R (eds), Applications of corporate governance, Standards Australia International, Sydney

Armstrong A Unger , Z ( 2009) Assessment, evaluation and improvement of university council performance, Evaluation journal of Australasia, 19(1): 46-54

ASX Corporate Governance Council (2003), Principles of Good Corporate Governance and Best Practice Recommendations, Australian Securities Exchange, Sydney.

---- (2007), Revised Corporate Governance Principles and Recommendations, Australian Securities Exchange, Sydney.

Bhagat, S and Black, B (2002), 'The Non-correlation between Board Independence and Long-term Firm Performance', Journal of Corporation Law,27(2):. 231-273. 
Bradley, D, Noonan, P, Nugent, H \& Scales, B (2009), Review of Australian Higher Education: Final Report, Department of Education, Employment and Workplace Relations, Canberra.

Callen, JL, Klein, A \& Tinkelman, D (2003), 'Board Composition, Committees, and Organizational Efficiency: The Case of Nonprofits', Nonprofit and Voluntary Sector Quarterly, vol. 32, no. 4, pp. 493-520.Cameron, J W (2003), Report of the Auditor-General on RMIT's finances, Auditor General Victoria, Melbourne

Chaganti, RS, Mahajan, V \& Sharma, S (1985), 'Corporate Board Size, Composition and Corporate Failures in Retailing Industry', Journal of Management Studies, vol. 22, no. 4, pp. 400-17.

Chen, K, Elder, R \& Hsieh, Y (2005), 'Corporate Governance and Earnings Management: The Implications of Corporate Governance Best-Practice Principles for Taiwanese Listed Companies', Journal of Contemporary Accounting \& Economics, vol. 3, no. 2, pp. 73-105

Dawkins, J 1988, Higher Education : A Policy Statement (Dawkins White Paper), Parliamentary Paper ,Australia. Parliament Department of Employment Education and Training, Canberra.

DEEWR 2008, Finance (2007), Financial Reports of Higher Education Providers, Department of Education, Employment and Workplace Relations, viewed 22/10/09 at:

$<$ http://www.deewr.gov.au/HigherEducation/Publications/FinanceReports/Pages/Finance2007.aspx>.

---- (2009), Transforming Australia's Higher Education System, Department of Education, Emplymnet and Workplace Relations, Canberra.

---- (2011), Higher Education Report 2009, Department of Education Employment and Workplace Relations, Canberra.

De Silva Loku Waduge, CS 2011, 'Governance and Performance: An Empirical Study of Australian Universities', PhD thesis, Victoria University.

De Silva, LWCS (2010), 'Governance Best Practice of Australian Universities', paper presented at Finance and Corporate Governance Conference, Latrobe University, Melbourne.AprilEisenberg, T, Sundgren, S \& Wells, MT 1998, 'Larger Board Size and Decreasing Firm Value in Small Firms', Journal of Financial Economics, vol. 48, no. 1, pp. 35-54.

Edwards, M 2000, 'University Governance: A Mapping and Some Issues', paper presented to LifeLong Learning Network National Conference, Melbourne, December, viewed 24.12.10 at: $<$ http://www.atem.org.au/pdf/Governance.pdf $>$.

---- 2003, 'Review of New Zealand Tertiary Education Governance ', viewed 24/12/10 at: $<$ http://www.atem.org.au/uploads/publications/20-Tertiary_Governance.pdf $>$.

Fielden, J (2008) Global Trends in University Governance viewed on 10th Jan 2010 at 1099079956815/Global_Trends_University_Governance_webversion.pdf

Greenwood, R \& Hinings, C (1996), 'Understanding Radical Organizational Change: Bringing Together the Old and The New Institutionalism', Academy of Management Review, vol. 21, no. 4, pp. 1022-54.

Harman, G \& Harman, K 2003, 'Institutional Mergers in Higher Education: Lessons from International Experience', Tertiary Education and Management, vol. 9, no. 1, pp. 29-44.

Harman, K \& Treadgold, E (2007), 'Changing Patterns of Governance for Australian Universities', Higher Education Research \& Development, vol. 26, no. 1, pp. 13-29.Hamilton, S (2002) Review of University Governance, Deaprtment of Education ,State of Victoria, Melbourne

Hoare, D 1995, Higher Education Management Review: Report of the Committee of Inquiry, Australian Government Publishing Service, Canberra.

Khanchel, I (2007) Corporate governance: measurement and determinant analysis. Managerial Auditing Journal 22(8):740-760

Klein, A (1998), 'Firm Performance and Board Committee Structure', Journal of Law and Economics, vol. 41, pp. 275-303.Kondra, A \& Hinings, C (1998), 'Organizational Diversity and Change in Institutional Theory', Organization Studies, vol. 19, no. 5, pp. 743-67.

Nelson, B (2003), Our Universities: Backing Australia's Future, Department of Education, Science and Training, Canberra.

OECD (2004), Principles of Corporate Governance, OECD,Viewed on 11 april 2007, available at: www.oecd.org/document/49/0,2340,en_2649_34813_31530865_1_1_1_1,00.html

Universities Australia, universities over view (2010) viewed on 15th Lan 2010 at http://www.universitiesaustralia.edu.au/content.asp?page=/universities/overview.htm 
Shivdasani,A and Zenner,M.(2004) "Best practice in Corporate governance: what two decades of research reveals", The Bank of American Journal of Applied Corporate Finance, 16(2/3): 29-37

Storey, H (1997), University Governance in Victoria, Report of the Ministerial Committee of Advice on University Governance in Victoria, Government of Victoria, Melbourne.

Swansson. JA, Mow. KE \& Bartos. S,(2005) Good university governance in Australia, National Institute for Governance, The University of Canberra. Refereed Proceedings of 2005 Forum of the Australasian Association for Institutional Research

Weir, CM, Laing, D \& McKnight, PJ (2002), 'Internal and External Governance Mechanisms: Their Impact on the Performance of Large UK Public Companies', Journal of Business Finance and Accounting vol. 29 , no. $5 \& 6$, pp. 579-611.

West, R., Review of Higher Education Financing and Policy (1998) Commonwealth of Australia, Canberra. Yermack, D (1996), 'Higher Market Valuation of Companies with a Small Board of Directors', Journal of Financial Economics, 40(2):185-211.

\section{Appendix 1 \\ COUNCIL COMMITTEES}

\begin{tabular}{|l|c|c|}
\hline Name of the University & Yes & No \\
\hline Existence of the audit committee & 1 & 0 \\
\hline Chair external & 1 & 0 \\
\hline Majority of external members & 1 & 0 \\
\hline $6<$ audit committee meetings & 1 & 0 \\
\hline $\begin{array}{l}\text { Existence of the nomination } \\
\text { committee }\end{array}$ & 1 & 0 \\
\hline CEO not the chair & 1 & 0 \\
\hline CEO not a member & 1 & 0 \\
\hline $\begin{array}{l}\text { Existence of the remuneration } \\
\text { committee }\end{array}$ & 1 & 0 \\
\hline CEO not a member & 1 & 0 \\
\hline CEO not the chair & 1 & \\
\hline Total & 10 & \\
\hline
\end{tabular}




\section{Appendix 2}

TRANSPARENCY IN REPORTING

Does the annual report show the following?

\begin{tabular}{|c|c|c|}
\hline Item & Yes & No \\
\hline \multicolumn{3}{|l|}{ COUNCIL STRUCTURE } \\
\hline Council size & 1 & 0 \\
\hline Council appointment process clear & 1 & 0 \\
\hline Expertise and skills of council members & 1 & 0 \\
\hline Council members are evaluated at regular intervals & 1 & 0 \\
\hline Roles and responsibilities of council members & 1 & 0 \\
\hline Duties of members and breeches & 1 & 0 \\
\hline Training program for existing members & 1 & 0 \\
\hline Training for new members & 1 & 0 \\
\hline \multicolumn{3}{|l|}{ COUNCIL PROCESS } \\
\hline Meetings and attendance of meetings & 1 & 0 \\
\hline COUNCIL COMMITTEES & 1 & 0 \\
\hline List of council committees & 1 & 0 \\
\hline Council committee meetings and attendance & 1 & 0 \\
\hline \multicolumn{3}{|l|}{ COMPLIANCE } \\
\hline List of compliances and disclosure & 1 & 0 \\
\hline Disclosure of significant event & 1 & 0 \\
\hline Strategic plan & 1 & 0 \\
\hline Mission & 1 & 0 \\
\hline Strategic goals & 1 & 0 \\
\hline Information of other business entities & 1 & 0 \\
\hline Risk statement & 1 & 0 \\
\hline Joint venture Risk analysis & 1 & 0 \\
\hline KPIs $\quad$ (1 for each year, max up to five) & & \\
\hline Student load statistics & 5 & \\
\hline Staff load statistics & 5 & \\
\hline Research grants & 5 & \\
\hline Research and publications & 5 & \\
\hline Graduate destination (full-time employment etc.) & 5 & \\
\hline Graduate outcome (overall satisfaction etc.) & 5 & \\
\hline Average enter score/student demand & 5 & \\
\hline Financial performance & 5 & \\
\hline Financial position & 5 & \\
\hline Total & 65 & \\
\hline
\end{tabular}


